\title{
Despre adaptarea grafică a numelor proprii din prima traducere a Septuagintei în limba română (Ms. 45)
}

\author{
Ana-Maria Gînsac* \\ Departamentul de Cercetare Interdisciplinar - Domeniul Socio-Uman, Universitatea „Alexandru Ioan Cuza”, \\ Str. Lascăr Catargi 54, 700107 Iași, România
}

\section{Despre articol}

Istoric:

Primit 5 decembrie 2015

Acceptat 13 decembrie 2015

Publicat 12 februarie 2016

Cuvinte-cheie: nume proprii traducere adaptare formală limba română Septuaginta

\begin{abstract}
Rezumat
Printre dificultățile cu care s-au confruntat întotdeauna traducătorii Bibliei se numără adaptarea numelor proprii din acest text în fiecare idiom. Unele nume proprii biblice au fost adaptate în limba română odată cu primele traduceri ale unor fragmente din Vechiul și din Noul Testament. Cele mai multe nume proprii biblice au fost însă adaptate pentru prima dată în limba română odată cu prima traducere românească a Septuagintei, efectuată de Nicolae Spătarul (Milescu) în a doua jumătate a secolului al XVII-lea și păstrată într-o copie manuscrisă revizuită (Ms. rom. 45) datînd din acelaşi secol. Sursa principală a acestei traduceri a fost o ediție a Septuagintei apărută la Frankfurt, în 1597. În spiritul literalismului care caracteriza traducerile Bibliei în epocă, tendința dominantă a traducătorului și a revizorilor a fost să conserve pe cît posibil forma numelor proprii din textul sursă, încercînd totodată să le integreze în grafia și în flexiunea limbii române. Pornind de la particularitățile formale ale numelor din textulsursă, ne propunem să descriem unele aspecte şi probleme legate de principiile grafice care au stat la baza transpunerii numelor proprii din sursa grecească în Ms. 45.
\end{abstract}

\section{Introducere}

Transpunerea numelor proprii (Npr) dintr-o limbă în alta se poate realiza prin cîteva procedee principale: traducere (înlocuirea materialului textual din limba-sursă cu echivalentul textual din limba țintă, de exem-

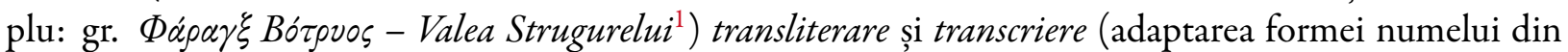
limba-sursă la sistemul grafic și morfologic al limbii-țintă $)^{2}$. Studiul adaptării formale la sistemul limbii române a numelor proprii scrise în alt alfabet decît cel latin presupune două direcții de cercetare:

1) studiul adaptärii grafice: transpunerea prin transliterare (înlocuirea fiecărui grafem dintr-un sistem grafic printr-unul dintr-un sistem grafic diferit) sau prin transcriere fonetică a $\mathrm{Npr}$ dintr-un alfabet în altul $^{3}$;

2) studiul adaptării morfologice: participarea Npr la „opozițiile de gen, număr, caz și determinare” ale limbii române (Ichim-Tomescu, 1978, p. 237).

Descriind modalitatea adaptării Npr ebraice în Septuaginta, specialiștii au evidențiat diversitatea transliterărilor și a transcrierilor existente pentru denominarea unor realităţi individuale, mai ales persoane și locuri. Astfel, studiind din această perspectivă cartea Iosua (Iisus Navi), care conține liste ample de Npr, Moatti-Fine (1996, p. 69-73) arată că la baza numeroaselor variante ale toponimelor din această carte biblică au stat mai mulți factori:

\footnotetext{
*Adresă de corespondență: anamaria_gansac@gmail.com.

${ }^{1}$ Pentru mai multe exemple, vezi Fernández (1977).

${ }^{2}$ Pentru diversele accepțiuni ale acestor termeni, vezi Catford (1965, p. 20-69) și Grass (2002, p. 114 ș.u.); pentru o sinteză a acestora, vezi Gînsac (2013).

${ }^{3}$ Termenii transliterare și transcriere sînt definiți de Catford (1965, p. 68-69). Evidențiind cele două modalități de adaptare, Savu (2011, p. 77-80) folosește termenul ,adaptare grafo-fonetică”.
} 
1) dificultatea de a citi și a identifica majoritatea numelor de locuri din textul ebraic;

2) alternanța între traducere și transliterare în cazul toponimelor descriptive compuse; uneori sînt pre-

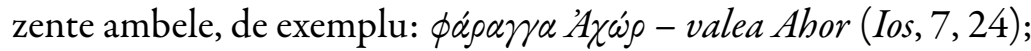

3) existența mai multor variante formale ale aceluiași nume, de exemplu: ebr. 'apēkāh („cetatea lui Iuda”) este transpus în limba greacă în forma Phakoua (Ios, 15, 53) în Codex Vaticanus sau Aphaka în versiunea din Codex Alexandrinus (Moatti-Fine, 1996, p. 73); printre altele, acest fenomen a fost explicat prin existența mai multor tradiții de vocalizare a textului ebraic (Krašovec, 2010, p. 89);

4) coexistența formelor elenizate și a celor neadaptate la sistemul limbii grecești; vezi 2).

Unele Npr biblice au fost adaptate în limba română odată cu primele traduceri ale unor fragmente din Vechiul și din Noul Testament: Evangheliarul slavo-român (1551-1553), Palia de la Orăștie (1581-1582), Codicele Bratul (1559-1560) etc. Astfel, cercetările privind Palia de la Orăşstie (1581-1582), text care cuprinde traducerea din limbile maghiară și latină a primelor două cărți ale Pentateubului, relevă lipsa unui sistem unitar de transpunere a Npr în limba română, situație explicabilă prin gradul diferit de cunoaștere a numelor (cele cunoscute și cele des întrebuințate s-au fixat într-o formă unică), relevanța acestora în text, utilizarea unor surse multiple, principiul nealterării în traducere a textului-sursă, nivelul de pregătire al traducătorului etc. (Pamfil, 1982; Gafton, 2007).

Cele mai multe Npr biblice au fost adaptate pentru prima dată în limba română odată cu prima traducere (integrală) a Septuagintei, efectuată de Nicolae Spătarul (Milescu), în a doua jumătate a secolului al XVII-lea, și păstrată într-o copie manuscrisă revizuită (Ms. 45) ${ }^{4}$ la Biblioteca Academiei Române, filiala din Cluj. Sursa principală a acestei traduceri a fost o ediție a Septuagintei apărută la Frankfurt, în 1597 (SEPT. 1597) $)^{5}$. Pe lîngă aceasta, pentru definitivarea textului din Ms. 45 au mai fost folosite și alte surse 6 , între care o ediție a textului grecesc tipărită la Londra, în 1653 (SEPT. 1653), aceasta fiind utilizată numai pînă la cartea 1 Paralipomenon, după cum se arată în Cuvîntu înainte cătră cititori (p. 909/2):

Iară și noi, pre lîngă izvodul lui Necoláie, am mai alăturat și alte izvoade grecești, pren care izvoade fost-au unul carele au fost tipărit la Englitéra, ci și acesta nu să potriviia cu cel de la Frangofort; pentru căci pren bogate locuri adăogea și pren bogate locuri lipsiia, nu veniia cu cestalalt; pentru acêea, lipsele nu s-au socotit, iar adaosele s-au pus, precum vom face doslușirea mai jos cu însemnări. Și așa am venit cu acela izvod pînă la Paralipómenon dentîi.

Literalitatea traducerii din Ms. 45, care presupune tendința spre conservarea formei Npr din textul-sursă, diferitele grafii cuprinse în acesta din urmă, implicarea a două alfabete diferite, precum și încercarea traducătorului de a adapta onomastica biblică în limba română sînt factori care au contribuit la gradul de integrare a Npr biblice din limba greacă în limba română. Pornind de la particularitățile formale ale Npr din textul grecesc ${ }^{7}$, ne vom limita în continuare la descrierea unor aspecte ale procesului adaptării grafice a Npr din Septuaginta (SEPT. 1597) în Ms. 45. Fiind vorba despre o traducere literală, în care se conservă adesea și forma morfologică a Npr din original, precizările legate de flexiunea Npr din textul grecesc sînt necesare pentru înțelegerea unor grafii din versiunea românească.

\section{Particularități formale ale Npr din Septuaginta}

O caracteristică generală a onomasticii din Septuaginta este aceea că, alături de cîteva Npr ebraice terminate în vocală, adaptate, de regulă, la sistemul morfologic al limbii grecești, există un număr mare de Npr

${ }^{4} \mathrm{Cu}$ privire la paternitatea copiei revizuite din Ms. 45, vezi Cândea (1979, p. 106-128), Onu (1984), Andriescu (1988, p. 17-25) și Ursu (2002, p. 7-133).

${ }^{5}$ Este vorba despre versiunea aldină, revizuită și corectată după edițiile apărute la Complutense, Antwerp, Strasbourg și Roma (Copinger, 2002, p. 94).

${ }^{6}$ Printre altele, este vorba despre o sursă slavonească (OSTR.) și una latinească (VULG.).

${ }^{7}$ Despre particularitățile formale ale Npr din Septuaginta, vezi Thackeray (1909), Moreno Hernández (1988), Dufour (1990) și Krašovec (2010). 


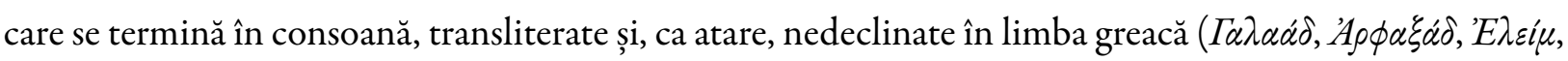

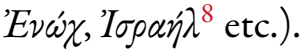

\subsection{Nume de persoană}

a) Thackeray (1909, p. 161) include în categoria Npr ebraice declinabile în limba greacă (după declinarea I) majoritatea numelor de persoană masculine care au terminaţie vocalică ('Tov $\varsigma \varsigma, M \omega v \sigma \tilde{\eta} \varsigma^{9}$ etc.) și o

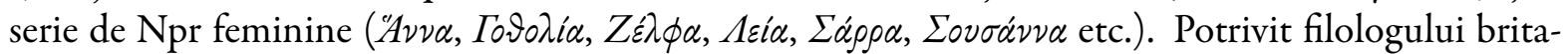

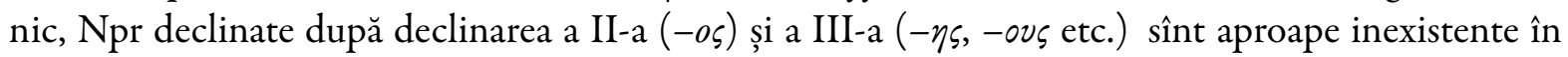

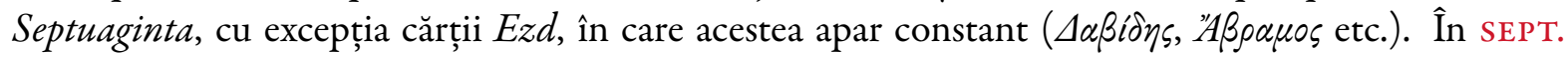

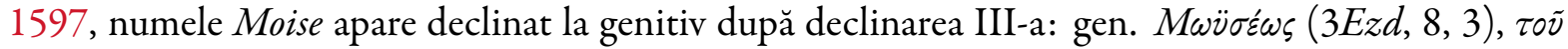

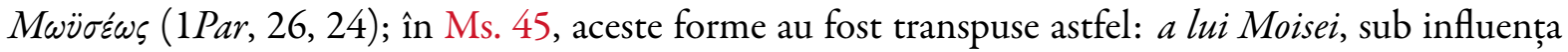
formei slavone moйcïn (Savu, 2011, p. 119), respectiv al lui Moiseu, cu adaptarea terminației grecești.

b) Npr biblice teoforice (care au în componență numele divinității, 'el) sînt de obicei elenizate prin adăugarea desinenței -ias (genitiv în -ov), fiind declinate după declinarea I, de exemplu: Avavias,

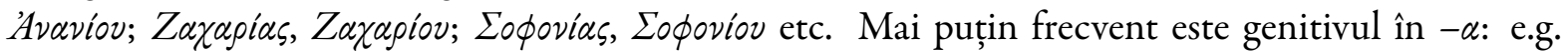

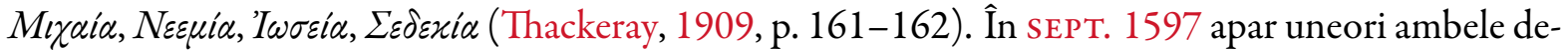
sinențe de genitiv ale numelui Mixaias-Mixaiov (4Reg, 22, 12) și Mıxaia (2Par, 34, 20)-, transpuse diferențiat în Ms. 45: lui Mihéu (cu păstrarea formei numelui prin realizarea cazului genitiv cu ajutorul articolului proclitic), respectiv Mihéii (cu adaptarea numelui la sistemul morfologic al limbii române prin articularea enclitică).

c) În Septuaginta, numele de persoană în - $\omega \nu$, terminație de origine ebraică ( $A \alpha \rho \omega \dot{\nu} \nu, \Sigma \alpha \mu \psi \sigma \omega \dot{\nu}$ etc.), sînt de obicei nedeclinate în limba greacă. Între acestea, un caz special îl reprezintă numele $\Sigma 0 \lambda$ ou $\omega \dot{\nu}$, care a trecut în limba greacă printr-un proces gradual de adaptare grafică și fonetică: $\sum \alpha \lambda \omega \mu \omega \dot{\nu}-\sum \alpha \lambda o \mu \omega \dot{\nu}$

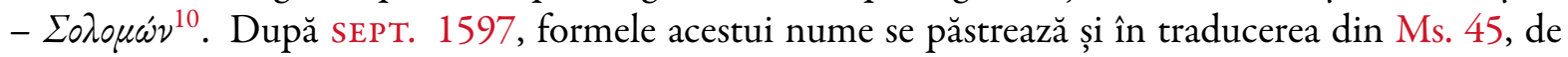
exemplu: Salomon $(3 E z d, 8,35)$ - Solomon (formă predominantă).

d) În SEPT. 1597, unele Npr de persoană au mai multe forme grafice, de exemplu: $A \mu \varepsilon \lambda \sigma a ́ \delta(D a n, 1,16)$

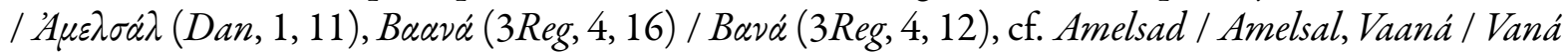
(Ms. 45).

\subsection{Nume de țăriși de popoare}

a) În Septuaginta, formele transcrise din ebraică coexistă cu cele elenizate ale numelor de locuri (vezi

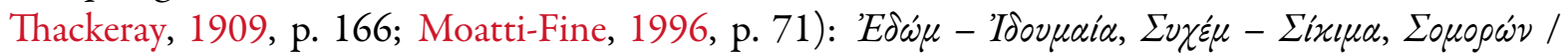

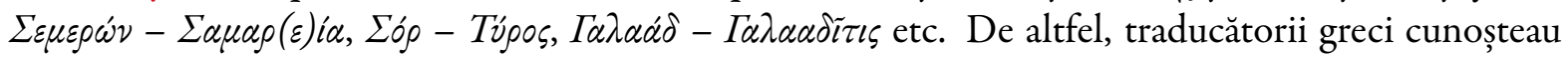
geografia biblică și, în consecință, și corespondentele grecești ale numelor de locuri și de popoare, de exemplu: Etiopia pentru Cuş, Capadochia pentru Caftor, Gavlon pentru Golan, Mesopotamia și Siria pentru Aram. În Ms. 45, acestea sînt păstrate întocmai după sursa grecească utilizată.

b) Referitor la Npr terminate în $-\alpha$, alături de numele de țări care se declină după declinarea I (e.g.

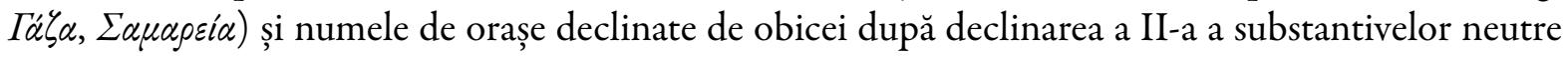

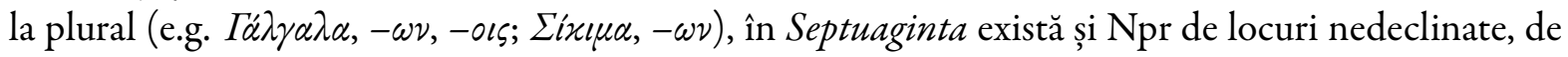

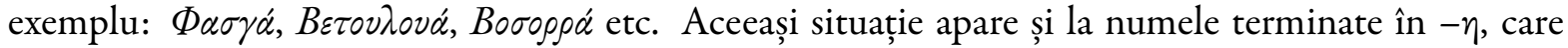

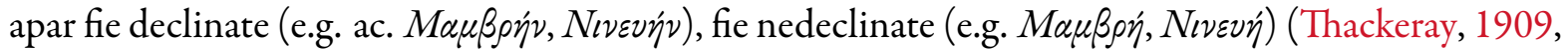
p. 162 și 167). Formele nedeclinate din SEPT. 1597 sînt conservate și în Ms. 45 (e.g. Fazgá, Mamvrí, Neneví, Vetuluá).

\footnotetext{
${ }^{8}$ În SEPT. 1597, formele nedeclinate sînt folosite ca atare pentru cazurile genitiv și dativ, nefiind integrate în flexiunea

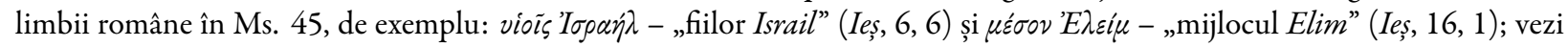
mai multe exemple la Ursu (2002, p. XII). Adaptarea morfologică a acestora în limba română nu face însă obiectul prezentului studiu.

${ }^{9}$ În conformitate cu normele actuale, am ortografiat Npr din SEPT. 1597 cu iniţială majusculă.

${ }^{10}$ Vezi, pentru explicații detaliate, Thackeray (1909, p. 162) și Dufour (1990, p. 56).
} 


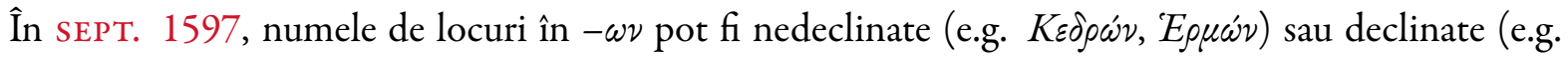
$A \sigma \varkappa \alpha \dot{\lambda} \omega \nu,-\omega \nu \alpha)$, acestea din urmă find uneori preluate în Ms. $45 \mathrm{cu}$ tot cu desinențele grecești: ac. $\varepsilon i \zeta$ Aбxá̀ $\omega v \alpha$ - Ascálona (Jud, 14, 19), dar Ascalon (1Mac, 10, 86).

c) Npr din SEPT. 1597 prezintă dublete (forme vocalizate / nevocalizate) de tipul: Ma $\gamma \varepsilon \delta \omega \dot{\omega}, M a \gamma \varepsilon \delta \delta \omega$ /

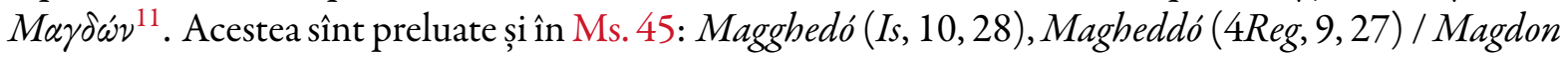
$(1 \operatorname{Reg}, 14,2)$.

d) Npr de popoare ebraice sînt și ele fie împrumutate, caz în care se păstrează terminația ebraică în $-\bar{i}$, -ith, fie adaptate la sistemul limbii grecești, de obicei cu terminațiile - aĩos (desemnînd membrul

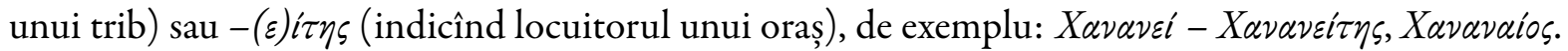
(Thackeray, 1909, p. 171) consideră că nu poate fi determinat principiul care a stat la baza alegerii

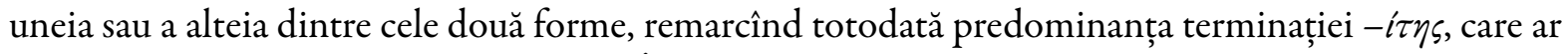

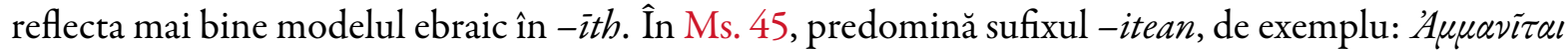

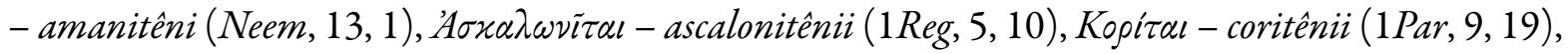

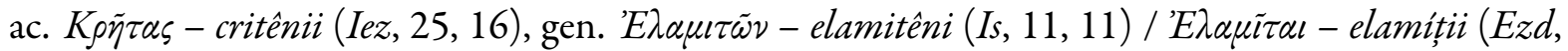

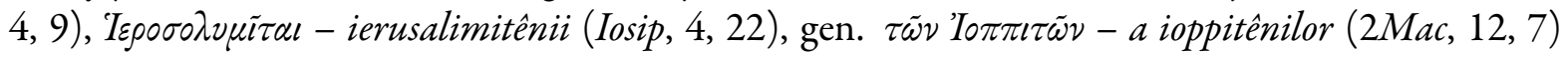

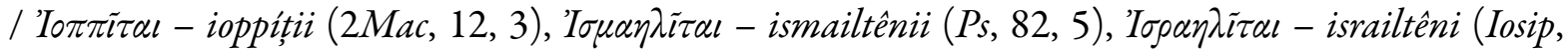

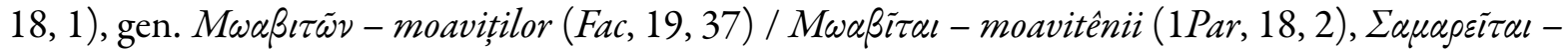

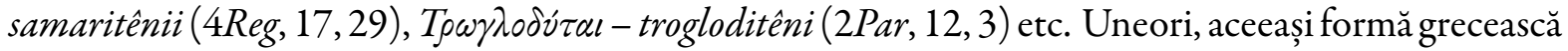
a etnonimului este redată cu ambele sufixe etnonimice românești, -ițiși -itean (i), de exemplu: „[...] au

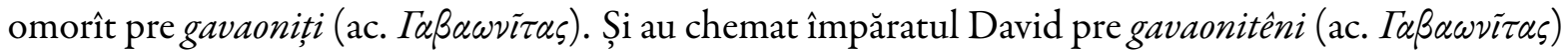

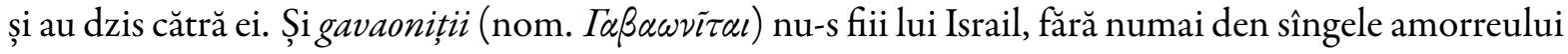
[...]" (2Reg, 21, 1-2).

În Ms. 45, unele nume de popoare sînt folosite pentru a denumi țara. Utilizat și în alte scrieri românești vechi, procedeul constă, arată Arvinte (1988, p. 49), în „folosirea numelui unui popor, la singular sau la plural, pentru a denumi țara locuită de acel popor”. Astfel, numele de popoare grecești la ac. sg.

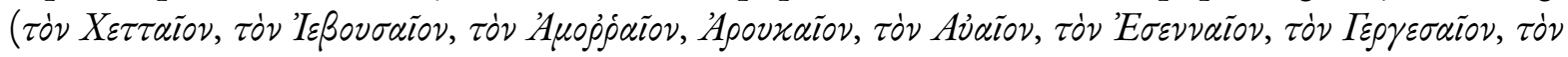
Apovadaiov etc.), care au fost adaptate în Ms. 45 în forma Hetteu, Ievuseu, Amorreu, Arucheu, Eveu, Esenneu, Ghergheseu, Arudeu (1Par, 1, 14-16: „Și pre Hetteu și pre Ievuseu și pre Amorreu și pre Ghergheseu și pre Eveu şi pre Arucheu și pre Esenneu pre Arudeu şi pre Aamareu”), denominează țări, fiind ortografiate în alfabet latin cu inițială majusculă.

\section{Particularităţi grafice ale Npr din Ms. 45}

Dincolo de evidenta străduință de a adapta onomastica biblică din Septuaginta de la Frankfurt (1597) în limba română, remarcăm preferința traducătorilor Ms. 45 pentru redarea cît mai exactă a originalului, precum şi încercarea de a aplica în mod coerent un sistem de transliterare și transcriere din limba greacă în limba română scrisă cu caractere chirilice.

\subsection{Preferința pentru redarea cît mai exactă a originalului}

În general, în Ms. 45 se optează pentru preluarea cît mai exactă a Npr din SEPT. 1597, transpunîndu-se uneori în limba română chiar terminațiile cazuale grecești, de exemplu: a) antroponime: Elivemas (Fac, 36, 41), Vithelias (Neem, 3, 20), Adonias (3Reg, 2, 19), Ananias (Iosip, 16, 21), lui Vanéas (3Reg, 2, 25),

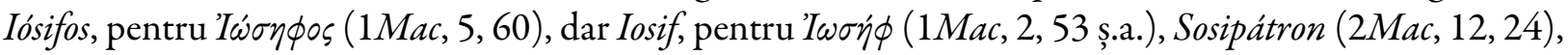
Sosipatros (2Mac, 12, 19) etc.; b) toponime: Aradion (Fac, 10, 18), Vachúros (3Ezd, 9, 24), Diospólis (Iez, 30, 16), Tíros (3Reg, 7, 13), Sichimon pentru $\sum_{i x i ́ \mu \omega \nu ~}(F a c, 33,18)^{12}$, etc. Nu credem că preluarea acestor nume în forma flexiunii grecești are legătură cu nerecunoașterea lor de către traducătorul sau revizorul Ms. 45 (Savu, 2011, p. 95), ci acest fapt evidențiază mai degrabă tendința de a prezerva forma din original.

\footnotetext{
${ }^{11}$ Vezi explicațiile și alte exemple la Moreno Hernández (1988, p. 276-277).

${ }^{12}$ Pentru alte exemple, vezi Ursu (2002, p. XIII).
} 
Unele Npr biblice intrate în uz anterior sau odată cu primele traduceri ale textelor folosite în serviciul liturgic, deci cunoscute (Gafton, 2007, p. 86), sînt redate într-o singură formă, altele prezintă variante, explicabile atît prin eventualele discontinuități la acest nivel în textul sursă, cît și prin încercarea continuă a traducătorului de a adapta forma numelor la sistemul limbii române. Astfel, forma neadaptată apare

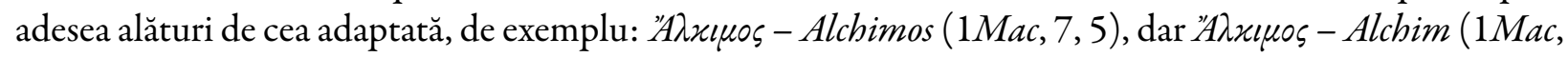
7,21 ș.a.).

Traducătorul Ms. 45 a păstrat cît mai fidel forma numelor din SEPT. 1597, preluînd și inconsecvențele din acest text, fără a standardiza, de regulă, numele care prezintă mai multe grafii în textul grecesc. De

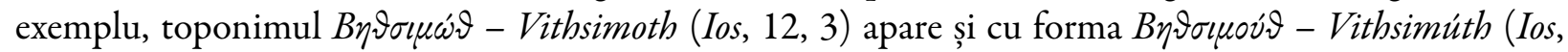

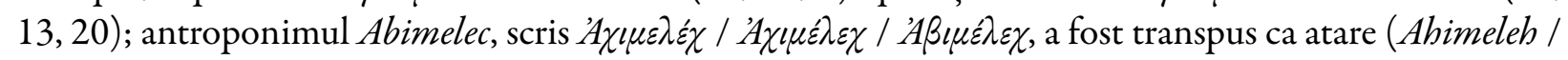
Avimeleh, cu sau fără accent) în majoritatea cazurilor ( 58 de ocurențe), cu cîteva excepții, cauzate, probabil,

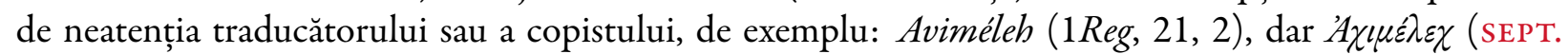
1597), Avimeleh (Ps, 51, titlu), dar $A \beta \iota \varepsilon \dot{\lambda} \varepsilon \chi$ (SEPT. 1597), transpus în limba română fără accent. În cazul

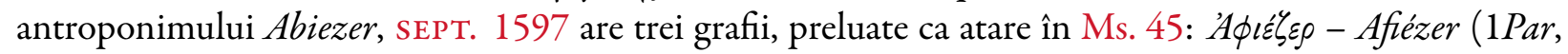

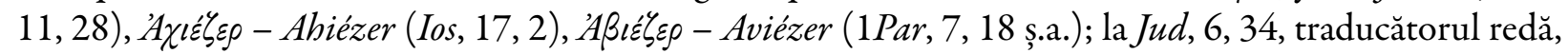
probabil, numele din glosa infrapaginală $(A \beta \iota \varepsilon \dot{\zeta} \varepsilon \rho)$, nu pe cel din text ( $A \beta \iota \dot{\zeta} \varepsilon \varepsilon \rho)$. Totuși, uneori apar și tentative de standardizare: Fud / Fudu - Фoú (Is, 66, 19; Naum, 3, 9; Fac 10, 6), dar Fud - Фoú (1Par,

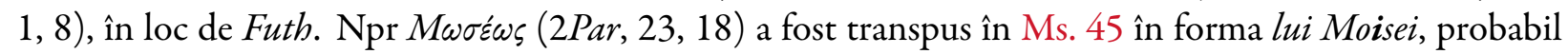

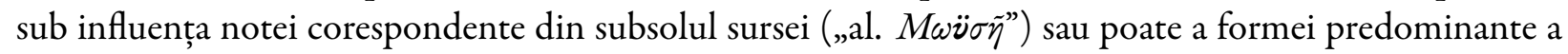
numelui în manuscris sau în alte texte din epocă (Moisi).

\subsection{Incercarea de a aplica în mod consecvent un set de norme de transliterare și transcriere a Npr din limba greacă în limba română scrisă cu alfabet chirilic}

O limbă notează sunetele altei limbi prin prisma corespondentelor fonetico-grafice care îi sînt proprii (Agafonov et al., 2006, p. 629). Astfel, adaptarea formală a Npr biblice din limba greacă în limba română scrisă cu alfabet chirilic trebuie discutată din perspectiva traductologiei, care presupune, în cazul de față, transpunerea Npr din limba greacă (SEPT. 1597) în limba română scrisă cu alfabet chirilic (Ms. 45), dar și din perspectiva transcrierii interpretative a numelor din alfabet chirilic (Ms. 45) în alfabet latin.

\section{a) Iniţiala majusculă}

În limba română, iniţiala majusculă este marca grafică a Npr. Analiza vechilor texte biblice românești relevă, însă, faptul că majuscula nu este o caracteristică constantă în marcarea formală a Npr (vezi PO, BB, MICU etc.). După modelul Septuagintei de la Frankfurt (1597), Npr nu sînt marcate prin inițială majusculă în Ms. 45. O excepție o constituie primele două cărți biblice, Facerea și Ieşirea. În unele cazuri, chiar în același fragment (ex. Num, 1,5-10), Npr sînt fie marcate, fie nemarcate prin inițială majusculă.

\section{b) Tratamentul geminatelor}

În Ms. 45 a fost conservată, de regulă, reduplicarea consoanelor în grafia Npr din textul sursă grecesc,

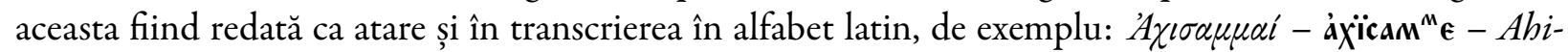

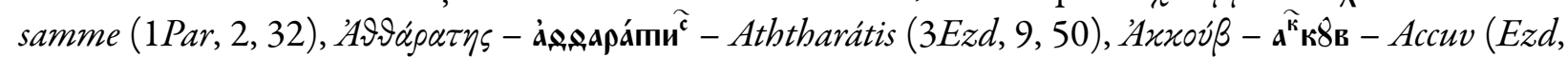

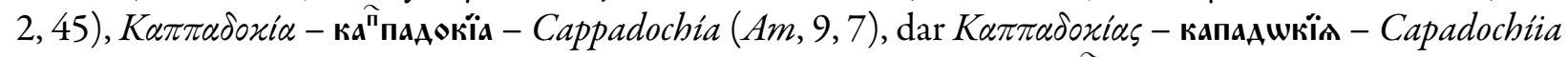

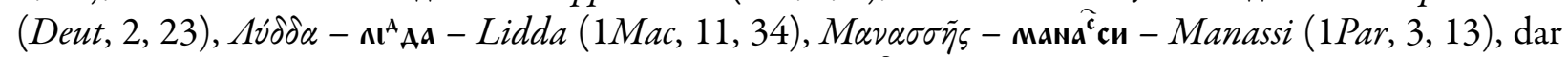

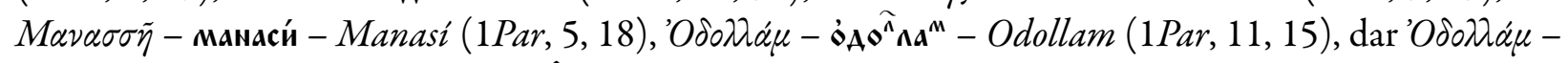
$\dot{\omega}_{\text {Aona }}{ }^{\text {M }}$ - Odolam $(2 M a c, 12,38)$. În Ms. 45 este conservată prin transcriere geminata aspirată $\vartheta$, care

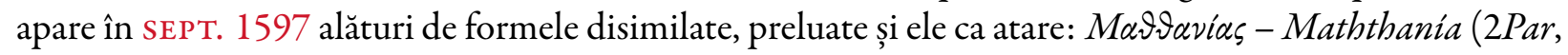

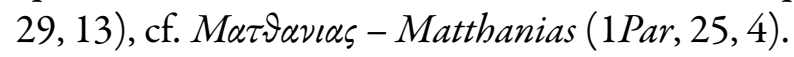

Raportat la textul sursă, există și inconsecvențe în transcrierea Npr, de exemplu: $\Sigma \omega \sigma \alpha ́ \nu \nu \alpha-$ cwcána -

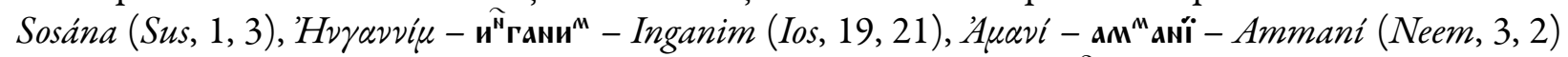

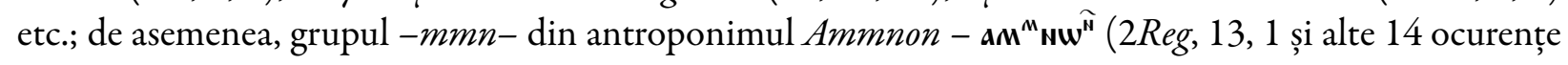


din aceeași carte biblică) nu reflectă forma numelui din original: 'A $\mu \nu \omega ́ \nu$ (SEPT. 1597). Aceste forme nu pot fi explicate nici prin sursele secundare (SEPT. 1653, OSTR., VULG.).

\section{c) Spiritele}

În Ms. 45, spiritul lin, notat în limba greacă ['], este redat cu regularitate în ortografierea Npr: Apaßí

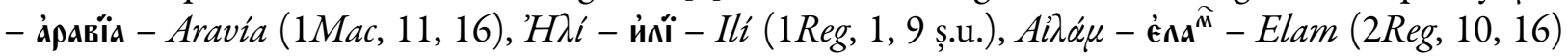
etc. Spiritul aspru, notat în limba greacă [ ' ] și pronunțat / $h /$, este transcris ca spirit lin în Ms. 45 în cazuri

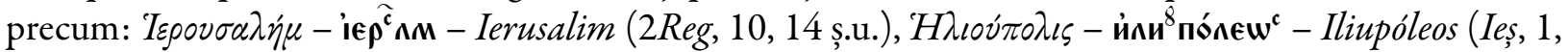

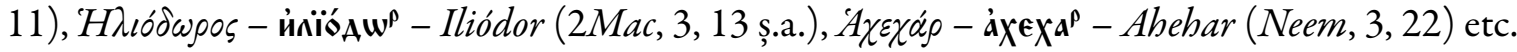

\section{d) Accentul}

Problema accentuării Npr de țări în limba română a fost discutată de Arvinte (2008, p. 110-124). Acesta a arătat, cu exemple concludente, că în perioada veche a limbii române existau două moduri de accentuare a numelor de țări terminate în -ia:

a) cînd accentul cade pe silaba penultimă (e.g. Asía, Chilichia, Machedonía, Persía, Rusía, Siría), Npr se încadrează în sistemul denominativ grecesc, care a fost folosit în limba română în perioada cuprinsă între secolele al XVII-lea și începutul secolului al XIX-lea, cînd circulația tipăriturilor în limba greacă era foarte mare în țările române;

ß) cînd accentul cade pe silaba antepenultimă (e.g. Arávia, Capadóchia, Gália, Grécia, Machidónia, Tráchia), este vorba despre sistemul latinesc de denominare de origine savantă, „care s-a constituit de-a lungul a mai bine de patru secole de cultură românească, fiind astăzi predominant în limba de cultură” (Arvinte, 2008, p. 113). În vechea română literară a existat o concurență între cele două moduri de accentuare.

Accentul nu este marcat, de regulă, în cazul Npr care conțin litere suprascrise, de exemplu: 'Evvá $\mu$ - énw ${ }^{m}$ - Enom (Ios, 18, 16), Vithaemec - вияаеме ${ }^{\widehat{\kappa}}($ Ios, 19, 27), Themanon - sеманw" $(1$ Par, 1, 45), Telmon -

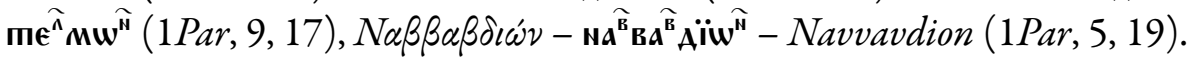

Poziția accentului pe ultima vocală a $\operatorname{Npr}(-\iota \alpha ́)$, mai ales în listele lungi de nume (genealogii), se explică prin faptul că aceste nume nu au fost adaptate la sistemul limbii grecești (nominativ în -ias, genitiv în -ía), ci au fost transliterate din ebraică (-ıá): Samá (1Par, 8, 13), Iesfá (1Par, 8, 16), Vareá (1Par, 8, 21), Adriá (1Par, 8, 22), Veriá (1Par, 23, 11) etc. Thackeray (1909, p. 162) explică acest fapt prin completarea listelor genealogice cu nume din alte surse în care numele nu erau declinate; dovadă ar fi Npr marcate

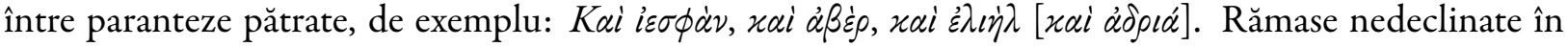
limba greacă, numele în $-(\varepsilon)$ เov́ au fost preluate ca atare în Ms. 45, de exemplu: Avdiú (Avd), Iliú (3Reg, 4 Reg).

Uneori, deși prezent în textul sursă, accentul este nemarcat în Ms. 45: Ierusalim / Ierusalím, Iothor / Ióthor, Iamna / Iamná, Ionathan / Ionáthan etc. În alte cazuri, printre ocurențele unor nume apar și forme

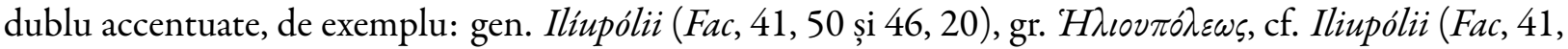

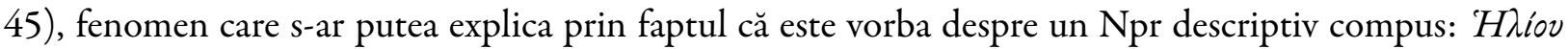

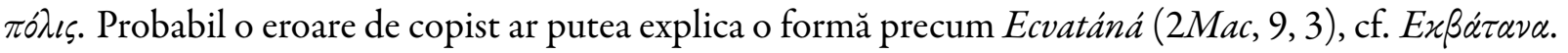

Accentul pe vocalele finale (Mamvri / Mamvrí, Sichima / Sichimá etc.) este preluat din textul sursă, unde marchează o formă nedeclinată în limba greacă a numelui (vezi supra, 2.2.b.).

\section{e) Transpuneri inexacte din limba greacă în limba română}

Unele forme din Ms. 45 nu reflectă forma din textul-sursă. Aceste inconsecvențe pot fi încadrate în cate-

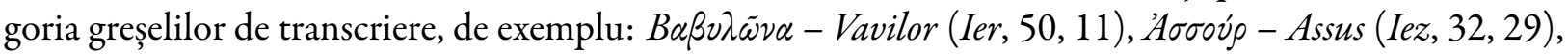

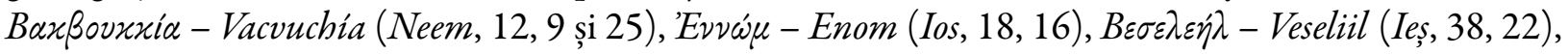

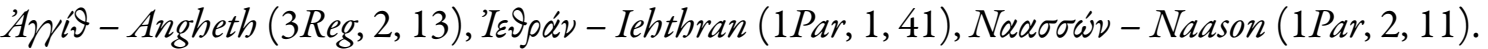

Fiind vorba despre un text manuscris, unele Npr (transpuse greșit sau refăcute după alte ediții) sînt 
corectate în text (deasupra rîndului sau în rînd) prin întregirea lor între croșete ${ }^{13}$, de exemplu: Vethará $\lfloor$ va $\rfloor$ $(\operatorname{Ios}, 15,6),\lfloor$ Si $\rfloor$ hem $(I o s, 17,2)$. Altele sînt corectate pe marginea textului, de exemplu: pentru Sovothé $(2 \operatorname{Reg}, 21,18)$ se indică pe margine corectura $X(h)$ deasupra slovei ọ $(t h)$, indicind forma Sovohé, cf. gr. Eoßoxai (SEPT. 1597).

Sporadic, în Ms. 45, unele prepoziții netraduse în limba română au fost atașate $\mathrm{Npr}$ : forma $\epsilon^{\widehat{\kappa}} \mathbf{B} \in \mathbf{Q} \mathbf{n} \mathbf{n} \mathbf{M} \mathbf{w}^{\widehat{\widehat{N}}}$ $(3 E z d, 5,31)$ redă secvența grecească $\varepsilon x$ B $B \vartheta \lambda \omega \omega \mu \omega \nu$ („din Vethlomon”), greșeală semnalată pe marginea textului printr-o vrahie roșie, marcînd traducerea separată a prepoziției grecești, i.e. den.

\section{f) Sistemul de transliterare și transcriere a Npr din limba greacă (SEPT. 1597) in limba română (Ms. 45)}

Pornind de la indicele de Npr al Ms. 45, redăm în Tabela 1 regulile de transpunere grafică a acestora din limba greacă în limba română scrisă cu alfabet chirilic, iar apoi în alfabet latin. Tabelul permite unele remarci privind transpunerea Npr grecești în limba română scrisă cu alfabet chirilic, precum și transcrierea lor în alfabet latin. Astfel, în privința consoanelor grecești (oclusive, siflante și lichide) nu există dificultăți majore în privinţa transpunerii lor din alfabet grecesc în alfabet chirilic. Există însă şi unele excepții:

a) consoana dublă $\psi$ este transliterată în Ms. 45 prin slova chirilică $\psi$, transcrisă în alfabet latin prin $p s$ :

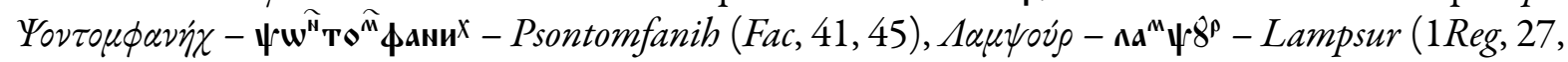
8), $\Sigma \alpha \mu \psi \alpha \dot{a}-\mathbf{c a}^{\mathrm{M}} \Psi \mathbf{a}-\operatorname{Sampsá}(E z d, 4,8)$. Uneori, deși prezentă în SEPT. 1597, consoana $\psi$ nu este redată în Ms. 45, de exemplu: $\sum \alpha \mu \psi \alpha i$ - $\mathbf{c a}^{\mathrm{M}} \mathbf{c}$ ś $-\operatorname{Samsê}(E z d, 4,17$ și 23);

$\beta)$ consoana velară geminată $-\gamma$ - este transcrisă în Ms. 45 prin grupul consonantic Nr $(n g): A \gamma \gamma \alpha i$ - a $\mathbf{a}^{\widehat{N}} \mathbf{i}$

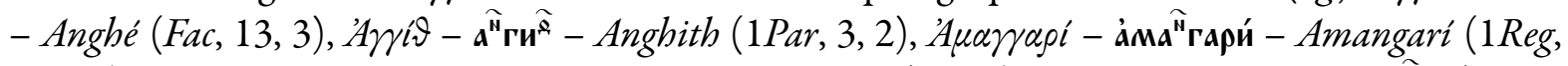

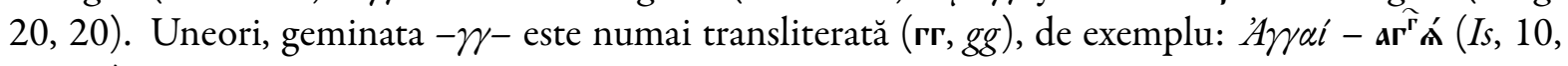
28-29);

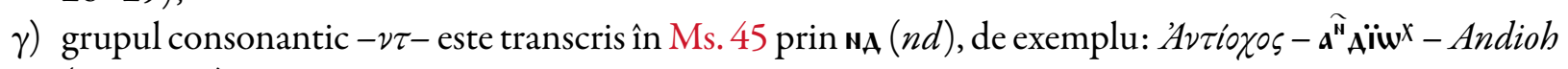
(Fac, 39, 1);

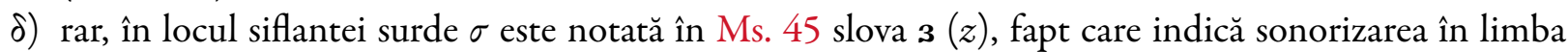

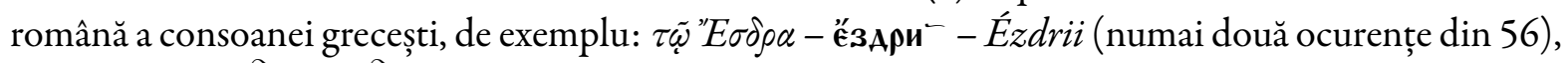

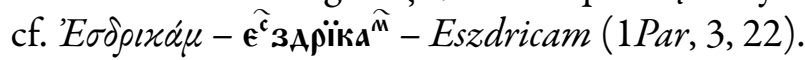

Referitor la vocalele grecești, acestea sînt transpuse în alfabet chirilic în mai multe moduri:

a) vocala grecească $\varepsilon$ este transpusă în Ms. 45 astfel:

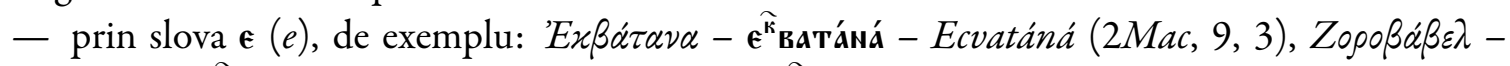

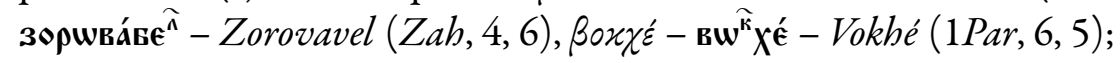

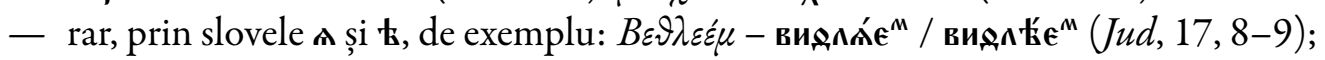

ß) vocala grecească lungă $\eta$ este redată în Ms. 45 astfel:

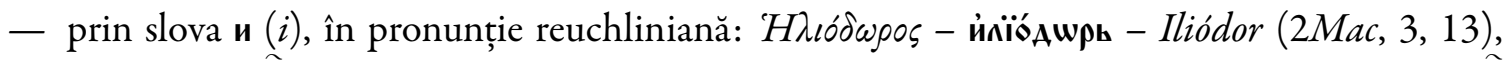

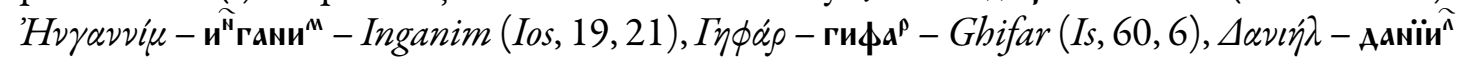

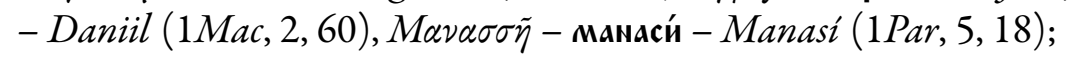

- rar, prin semnul - (i), în pronunție reuchliniană: $P \varepsilon \eta \lambda \dot{\alpha}-\boldsymbol{\rho} \epsilon^{-}{ }^{-} \mathbf{a}-$ - Reilá (1Par, 2, 15);

- rar, prin slova $\mathbf{\epsilon}(e): H \sigma \alpha \tilde{v}-\dot{\mathbf{\epsilon}} \mathbf{c} \widehat{A}^{\mathbf{B}}-E s a v(N u m, 24,18)$;

$\gamma$ ) vocala grecească $\ddot{\imath}$ este redată în Ms. 45 în două moduri. În limba greacă, cînd $\iota$ este precedat de o vocală cu care nu formează un diftong, este notat $\ddot{i}$, fiind transcris în Ms. 45 astfel:

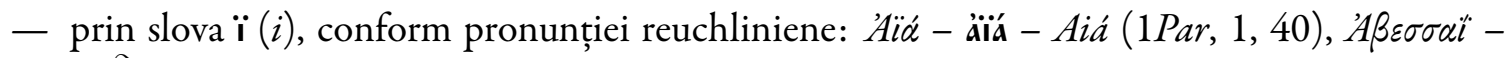

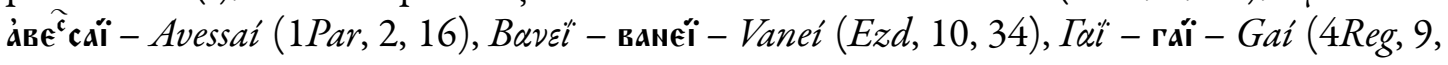
27);

- rar, prin semnul - $(i)$, conform pronunției reuchliniene: Kä̀vav-ка има - Cainán (1Par, $1,2)$;

\footnotetext{
${ }^{13}$ Rolul acestor semne este explicat în Cuvîntul înainte către cititori (p. 909): „Iar unde vei vedea acesta semnu cu roșiu \lfloor\rfloor și la mijloc iarăși cuvinte, să știi că l-am aflat mai mult întru izvodul Englitérii”.
} 


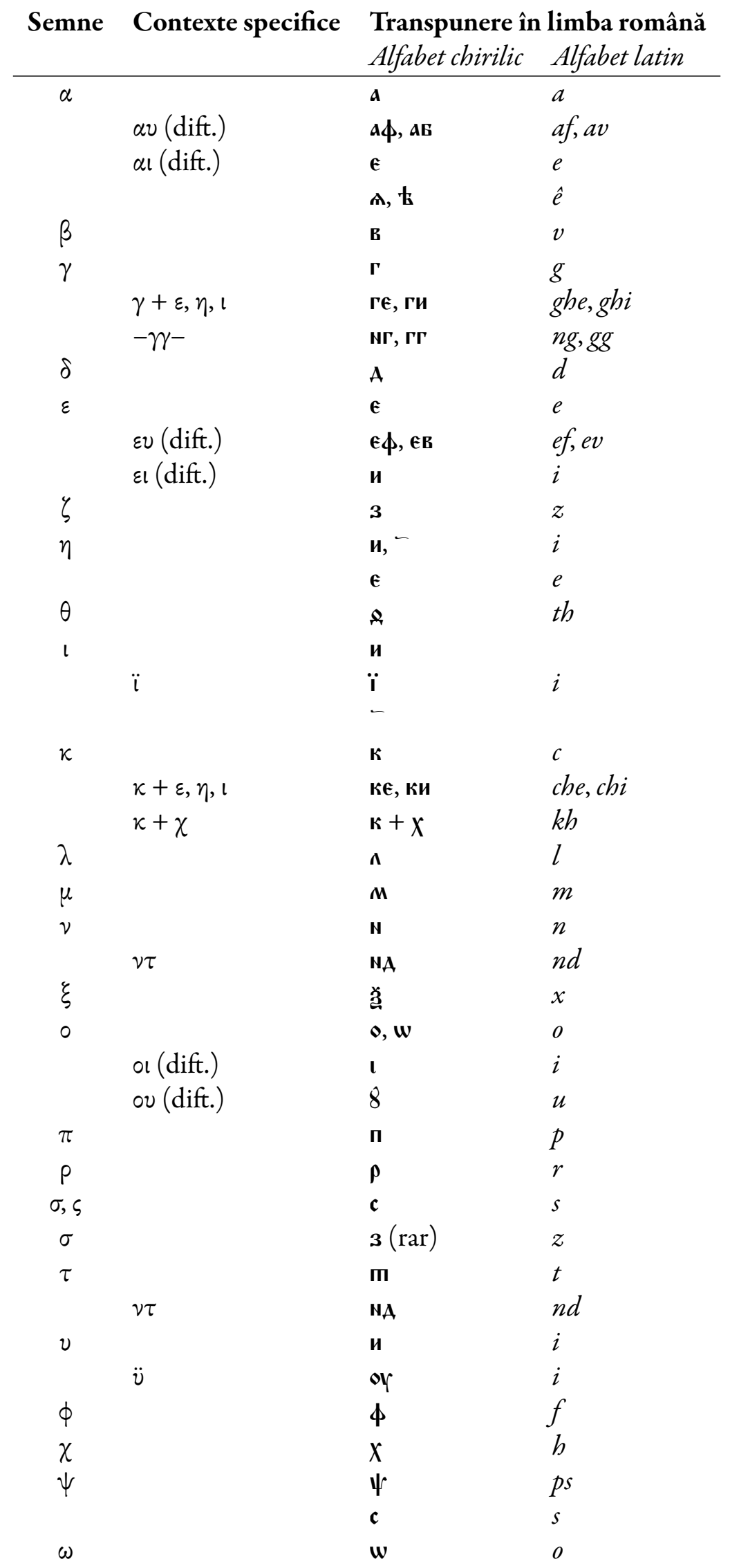

Tabela 1: Sistemul de transliterare și transcriere a Npr din SEPT. 1597 în Ms. 45. 


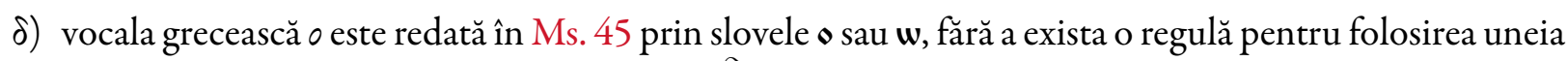

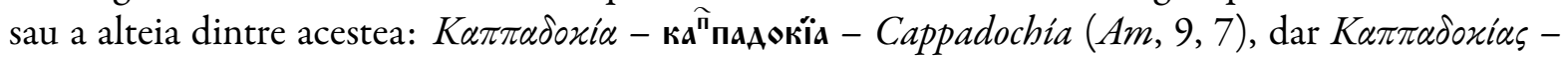

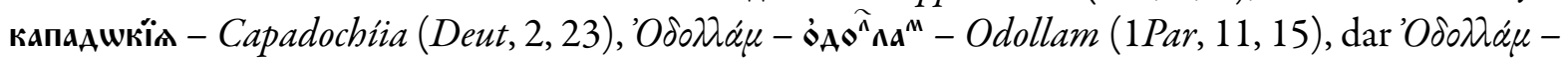

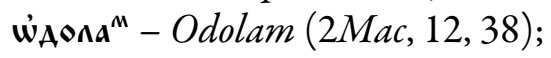

$\varepsilon)$ vocala grecească $v$ este transcrisă în Ms. 45, conform pronunției reuchliniene, prin slovele и și $\mathbf{I}(i)$ :

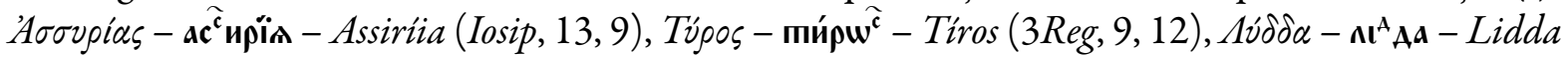
$(1 M a c, 11,34)$. În limba greacă, atunci cînd vocala v este precedată de o altă vocală cu care nu formează

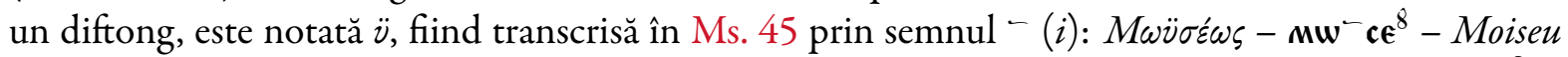

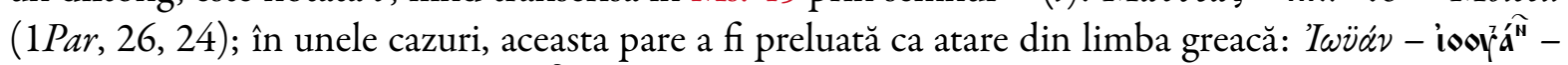
Ioián (1Par, 1, 5), dar 'Iẅ̈áv - iw'- $\mathbf{a}^{\widehat{N}}$ - Ioián (1Par, 1, 7).

Transpunerea unor diftongi din limba greacă în alfabet chirilic ridică unele probleme:

a) diftongul grecesc $\alpha \iota$ este transcris în Ms. 45 astfel:

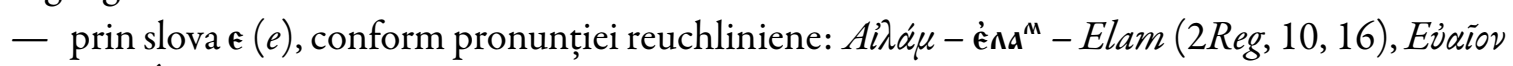
- е́ве ${ }^{8}$ - Eveu (1Par, 1, 15), Bajaı́́ - варе́́ - Vareá (1Par, 8, 21);

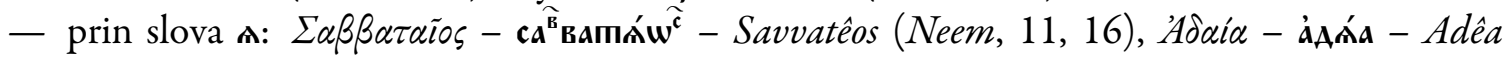

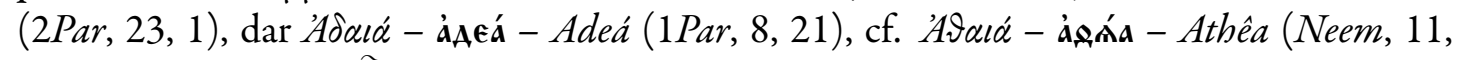

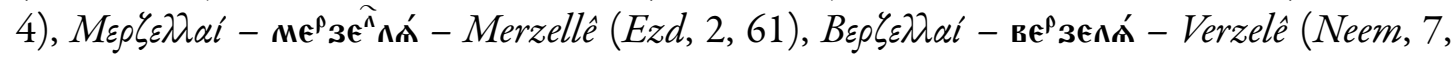
63). Am transcris slova chirilică a prin semnul $\hat{e}$, întrucît echivalează diftongul grecesc $\alpha \iota$, pronunțat /e/, conform rostirii reuchliniene;

$\beta$ ) diftongul grecesc $\alpha v$ este transcris în Ms. 45, alternativ, prin aф sau aв (af, av), conform pronunţiei

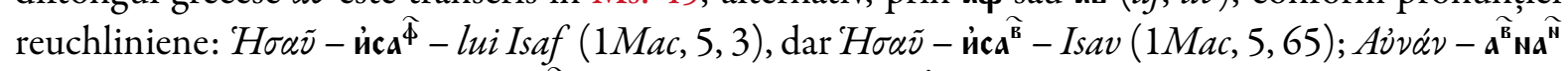

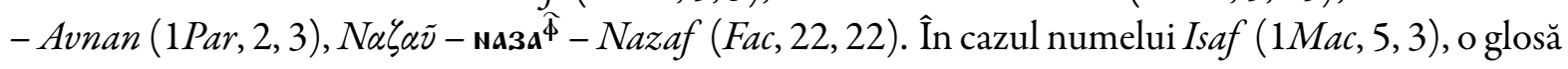
marginală indică lecțiunea $v$ în loc $\operatorname{de} f$;

$\gamma)$ diftongul grecesc $\varepsilon \iota$ este transcris în Ms. 45, conform pronunției reuchliniene, prin slovele и sau $\ddot{i}(i)$ :

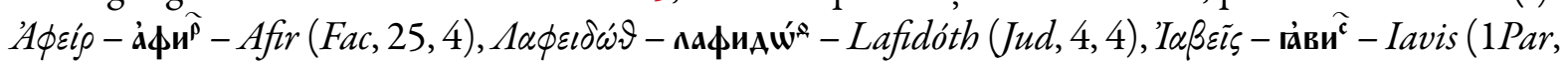
10, 11), ¿quájeı́ - camápïa - Samária (2Par, 28, 15);

$\delta)$ urmat de o consoană, grupul vocalic grecesc $\varepsilon v$ este transcris în Ms. 45 conform pronunției reuchliniene, astfel:

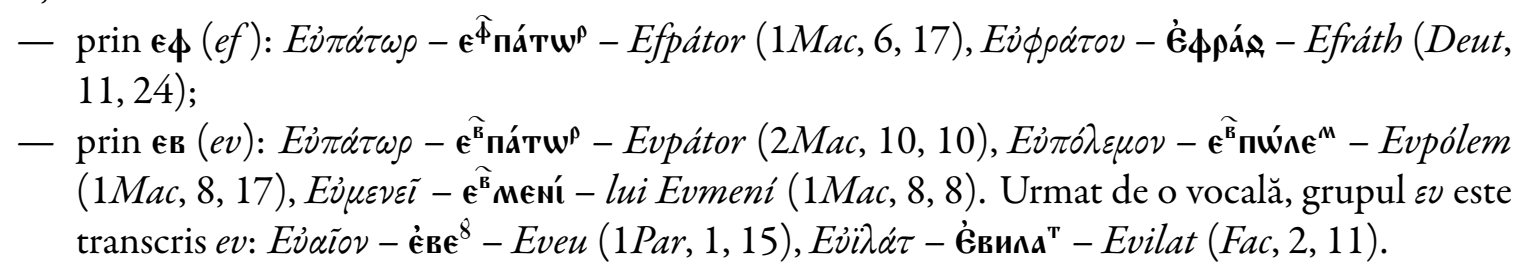

Terminațiile grecești - aĩos și - aĩov sînt transcrise în Ms. 45 prin grupul e8 (eu): Axpåaĩos - Abratheu (Preambul Est, 13), 'Axpavaiov - Arhatheu (Preambul Est, 14) etc.

\section{Concluzii}

Forma grafică a Npr din Ms. 45 reflectă, cu unele mici excepții (greșeli de transliterare/transcriere, unele cazuri de standardizare etc.), forma acestora din textul-sursă principal, Septuaginta de la Frankfurt (1597), sursele secundare nefiind luate în considerare în această privință. Unele forme sînt corectate în text după versiunea de la Londra (1653) a textului grecesc, folosită de revizorul traducerii lui Nicolae Spătarul (Milescu) pînă la cartea 1 Paralipomenon.

La rîndul său, textul-sursă prezintă numeroase inconsecvențe în privința formei Npr, cauzate de principiul literalităţii traducerii, care a impus în general conservarea formei Npr ebraice şi numai sporadic adaptarea lor la sistemul morfologic al limbii grecești. În Ms. 45 se conservă fenomenele anomale din textul sursă (multiplele grafii ale aceluiași nume și diferitele modalități de denominare a aceluiași individ), încercările de standardizare a unor forme și greșelile de transcriere din alfabet grecesc în alfabet chirilic 
find rare. De asemenea, dincolo de existența mai multor slove chirilice pentru redarea aceluiași semn grafic grecesc, se poate evidenția totuși încercarea traducătorului/revizorului de a aplica în mod consecvent un set de norme de transliterare și de transcriere a Npr din limba greacă în limba română (conform pronunției reuchliniene). Studiul sistematic al specificului integrării Npr din textul grecesc în flexiunea limbii române va întregi imaginea asupra specificului formal al Npr din Ms. 45.

\section{Bibliografie}

\section{A. Surse}

ВА $=$ La Bible d'Alexandrie, VI. Jésus (Josué), Les Éditions du Cerf, Paris, 1996.

$\mathrm{BB}=$ Biblia 1688, text stabilit şi îngrijire editorială de Vasile Arvinte şi Ioan Caproşu, volum întocmit de Vasile Arvinte, Ioan Caproşu, Alexandru Gafton, Laura Manea, N. A. Ursu, vol. I-II, Editura Universității „Alexandru Ioan Cuza”, Iaşi, 2001 (I), 2002 (II).

MICU = Biblia, adecă Dumnezeiasca Scriptură a legii vechi și a ceii noao, toate care s-au tălmăcit depre limba elinească pre înțelesul limbii românești [Biblia de la Blaj - 1795, Ediție jubiliară în reproducere anastatică și transcriere interpretativă, coord. Ioan Chindriș și Eugen Pavel, Roma, 2000], Blaj, 1795.

MLD = Biblia de la Bucureşti (1688), în seria Monumenta lingua Dacoromanorum. Pars I. Genesis, Editura Universitătiii ,Alexandru Ioan Cuza”, Iași, 1988; Pars XXI. Machabæorum I, Machab๕orum II, Machabeorum III, Editura Universității „Alexandru Ioan Cuza", Iași, 2015.

Ms. 45 = Biblioteca Filialei Cluj a Academiei Române, fondul Blaj, Manuscrisul românesc nr. 45 [c. 1683-1686]. OSTR. = Бивлига сирекь кмигы Ветхаго и Новаго Завета по назыкоу словенскоу [...], Ostrog, 1581.

PO = Palia de la Orăştie: 1581-1582, text, facsimile, indice şi ediție îngrijită de Viorica Pamfil, Editura Academiei Române, Bucureşti, 1968.

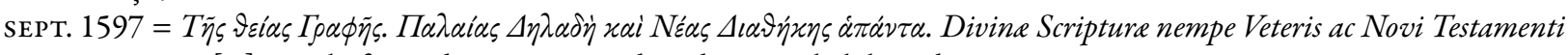
omnia, Grace [...], Frankofurti ad Møenum, apud Andrex Wecheli hæredes, 1597.

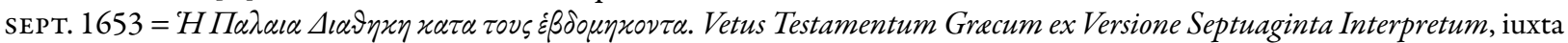
Exemplar Vaticanum Romæ editum, Accuratissime [...], Londini, Excudebat Rogerus Daniel [...], MDCLIII.

vULG. = Biblia ad vetustissima exemplaria castigata [...], Antverpix, Ex officina Christophori Plantini, MDLXV.

\section{B. Referințe}

Agafonov, C., Grass, T., Maurel, D., Rossi-Gensane, N. \& Savary, A. (2006). La traduction multilingue des noms propres dans PROLEX, în „Meta: journal des traducteurs”, LI (4), p. 622-636, CrossRef.

Andriescu, Al. (1988). Locul Bibliei de la București în istoria culturii, literaturii și limbii române literare, în MLD, Pars I. Genesis, Iași, p. 7-45.

Arvinte, V. (1988). Studiu lingvistic asupra primei cărți (Facerea) din Biblia de la București (1688), in comparație cu Ms. 45 și Ms. 4389, în MLD, Pars I. Genesis, p. 47-105.

Arvinte, V. (2008). Român, românesc, România. Studiu flologic, ediția a III-a (definitivă), Casa Editorială „Demiurg”, Iaşi.

Ballard, M. (2004). Le nom propre en traduction, în „Babel”, vol. 39, nr. 4, p. 194-213, CrossRef.

Catford, J.-C. (1965). A Linguistic Theory of Translation. An Essay in Applied Linguistics, Oxford University Press, London.

Cândea, V. (1979). Rațiunea dominantă. Contribuții la istoria umanismului românesc, Editura Dacia, Cluj-Napoca.

Copinger, W.-A. (2002). The Bible and its Transmission. Being an Historical and Bibliographical View of the Hebrew and Greek Texts [...], Martino Publishing, Mansfield Centre [prima ediție: Londra, 1897].

Dufour, J.-P. (1990). La Transcription des noms propres dans la Bible anglaise avec références faites à la Bible dite «Version Autorisée» (1611), în Yannick Le Boulicaut (éd.), „Onomastique biblique: des richesses de la Bible hébraïque aux usages en langues modernes. Actes du Colloque des 4 et 5 novembre 1988", Université catholique de l'Ouest, Angers, p. 55-61.

Fernández, M.-N. (1977). Nombres propios y etimologias populares en la Septuaginta, în „Sefarad”, XXXVII, p. 239-260.

Gafton, Al. (2007). Palia de la Orăşstie ca traducere, în Alexandru Gafton, Vasile Arvinte, Palia de la Orăștie (1582), II. Studii, Editura Universității „Alexandru Ioan Cuza”, Iaşi, p. 81-91.

Gînsac, A.-M. (2013). Teonimie românească. Concept, metodă, probleme, Editura Universităţii „Alexandru Ioan Cuza”, Iaşi.

Grass, T. (2002). Quoi! Vous voulez traduire «Goethe»? - Essai sur la traduction des noms propres allemand-français, Peter Lang, Berne.

Ichim-Tomescu, D. (1978). Observații asupra adaptării morfologice a toponimelor străine în limba română, în „Limba română”, XXVII, nr. 3, p. 237-242.

Krašovec, J. (2010). The Transformation of Biblical Proper Names, T\&T Clark International, New York - London.

Moatti-Fine, J. (1996). Les noms de lieux dans Jésus (Josué), în BA, vol. VI, p. 69-89.

Moreno Hernández, A. (1988). El tratamiento de los nombres propios en los textos de Vetus Latina (I II Samuel), în „Emerita. Revista de lingüística y filología clásica", LXI, fasc. 2, p. 271-287. 
Onu, L. (1984). Concordanțele lingvistice sau capcanele stabilirii paternității unui text. Probleme de metodă, în „Limba română”, XXXIII, nr. 2, p. 119-132.

Pamfil, V. (1982). Toponime în Palia de la Orăștie, în „Studii de onomastică”, nr. 3, p. 202-222.

Rosetti, Al. (1968). Istoria limbii române de la origini pînă în secolul al XVII-lea, Editura pentru Literatură, București.

Savu, S.N. (2011). Numele propriu în textul biblic românesc. Studiu asupra procesului de adaptare formală, Universitatea „Alexandru Ioan Cuza” din Iași (teză de doctorat).

Ștef, A.-F. (1996). Manual de greacă veche, Humanitas, București.

Thackeray, H.-J. (1909). A Grammar of the Old Testament in Greek According to the Septuagint, vol. I, Georg Olms Verlag, New York, p. 160-172.

Ursu, N.-A. (2002). Noi informații privitoare la manuscrisul autografși la textul revizuit al Vechiului Testament tradus de Nicolae Spătarul (Milescu), în BB, p. I-LIV. 